\title{
Has the increase in the availability of generic drugs lowered the price of cardiovascular drugs in South Africa?
}

\author{
Varsha Bangalee*, Fatima Suleman ${ }^{1}$ \\ Discipline of Pharmaceutical Sciences, School of Health Sciences, University of KwaZulu-Natal, Westville Campus, \\ Private Bag X54001, Durban, 4000, KZN, South Africa
}

\section{A R T I C L E I N F O}

Article history:

Received 6 February 2015

Accepted 13 October 2015

Available online 26 February 2016

\section{Keywords:}

Medicine pricing

South Africa

Generic drugs

Single exit price

Price competition

\begin{abstract}
A B S T R A C T
Background: This research focuses on pharmaceutical competition in South Africa where concurrent pricing legislation is being implemented without monitoring the consequences on generic drug competition and usage.

Objective: To examine the relationship between originator drug prices and the number of generic brands within the cardiovascular class of drugs and to compare South African prices with international reference prices.

Method: Data on private sector drug prices was sourced from the South African Medicine Price Registry. The relationship between the median proportional price and the number of brands in the therapeutic class was analysed using correlation analysis. International reference prices were obtained from the Management Sciences for Health International Drug Price Indicator Guide (2012 edition).

Results: A weak correlation between originator and generic drug prices and the number of available brands was observed, the exception being diuretic drugs. The median prices per strength of the originator generic were still higher than the most expensive generic version manufactured by any other company, the exception being telmisartan. Comparison of price ratios between the originator drug, lowest priced generic and international reference price values revealed that the originator drug prices had a median price ratio of 20.99 (interquartile range 7.31-53.46) and the lowest priced generics had a median price ratio of 4.28 (interquartile range $2.10-8.47$ ).

Conclusion: Increased generic competition is not a predictor of lower drug prices. The study also concludes that the current South African pharmaceutical policies have not yet achieved the lowest prices for drugs when compared internationally.

(C) 2015 The Authors. Publishing services by Elsevier B.V. on behalf of Johannesburg University. This is an open access article under the CC BY-NC-ND license (http:// creativecommons.org/licenses/by-nc-nd/4.0/).
\end{abstract}

\footnotetext{
* Corresponding author. Tel.: +27 31 2607980; fax: +27 312607792.

E-mail addresses: bangalee@ukzn.ac.za (V. Bangalee), sulemanf@ukzn.ac.za (F. Suleman).

${ }^{1}$ Tel.: +27 31 2607941; fax: +27 312607792.

Peer review under responsibility of Johannesburg University.

http://dx.doi.org/10.1016/j.hsag.2015.10.004

1025-9848/@ 2015 The Authors. Publishing services by Elsevier B.V. on behalf of Johannesburg University. This is an open access article under the CC BY-NC-ND license (http://creativecommons.org/licenses/by-nc-nd/4.0/).
} 


\section{Introduction}

Access to therapeutic drugs forms an integral part of any successful healthcare system (Bangalee, 2015). The high cost of therapeutic drugs, which has often been cited as a barrier to accessibility to essential medicines, has led to the promotion of generic drug consumption in South Africa.

The restructuring of the South African public health sector post-1994 led to the development and implementation of the National Drug Policy (NDP) in 1996. The economic objective of the NDP was to decrease the cost of therapeutic drugs in both the private and public sectors (Department of Health, 1996). In May 1997, The Medicines and Related Substances Control Amendment Act 90 (hereinafter referred to as "the Act") was tabled at parliament (Deroukakis, 2007). It was implemented to allow government to undertake a variety of actions in order to reduce drug prices and improve the affordability of medicines in line with the economic objectives of the NDP. The Act, implemented on 2 May 2003, mandates pharmacists to inform all private patients buying prescribed medicines about the benefits of generic alternatives (Deroukakis, 2007).

In addition to the mandatory offering of generic substitution, the 1997 amendments to the South African Medicines and Related Substances Act, in terms of section 18A, banned "bonusing" (preventing pharmaceutical manufacturers from offering discounts and/or rebates to patients or healthcare providers) and with section $22 \mathrm{G}$ this led to the formation of a "pricing committee" which was tasked with constructing "transparent pricing mechanisms" (Nicolosi \& Gray, 2009). The high levels of discounting and payment of incentives within the pharmaceuticals supply chain had raised serious concerns in the Department of Health (DOH) as these practices did not pass the savings on to the consumer. Retail pharmacies and dispensing doctors on the other hand were able to capitalise on these incentives while consumers continued to pay the official manufacturers' "listed" price (Hawkins, 2011). This also countered the effect of generic substitution as evidence revealed that in many cases doctors and pharmacists were not always agreeable to substituting the lower priced generic but would rather dispense the more profitable product (Hawkins, 2011). This lack of transparency in prices in the supply chain as well as the loss of benefits to consumers led to the prices of pharmaceutical drugs being regulated by the single exit price (SEP) legislation in 2004. This meant that drug manufacturers could only sell their products at one price to all their customers, regardless of the nature of the customer's order size and consumption levels (Republic of South Africa, 1997). The implementation of SEP in the private sector resulted in a significant shift from a free market to a regulated one in order to ensure transparent pricing practices for the industry. However, there is very little research on whether the implementation of this pricing policy has impacted on the use of generic drugs, and this study attempted to look into this area by selecting a particular group of drugs to investigate.

Globally, cardiovascular diseases (CVD) are responsible for $30 \%$ of all deaths, with the greater majority $(80 \%)$ of these deaths occurring in developing countries (van Mourik, Cameron, Ewen, \& Laing, 2010). Although HIV/AIDS remains the leading overall cause of mortality in sub-Saharan Africa, cardiovascular disease is the second leading killer and is first among individuals over the age of 45 years (Lopez, Mathers, Ezzati, Jamison, \& Murray, 2006). Thus, "in South Africa approximately 195 people die per day due to CVD, representing about $20 \%$ of the daily deaths due to HIV/AIDS" (Steyn, 2007). There is currently minimal information on the cost of CVD treatment in South Africa; however, the use of generic drugs could potentially address the need to reduce treatment costs. Furthermore, the growth of the South African generic pharmaceutical market is set to rapidly accelerate owing to the expiry of a number of patents especially in the cardiovascular category (Moorad, 2012). While previous studies revealed the price-lowering effect of generic competition with respect to the number of sellers in the overall market (Cook, 1998; Fatokun, Ibrahim, \& Hassali, 2011), very little data is available on this concept within a specific drug therapeutic class, let alone in South Africa, which has the additional policy of the SEP.

\subsection{Aims of the study}

The aim of this study was to examine the relationship between originator drug pricing and the number of available generic brands within the cardiovascular drug class in the context of SEP legislation, and to compare South African drug prices with international drug prices.

\section{Research method and design}

The quantitative study design was a secondary data analysis based on data collected on the five classes of cardiovascular drugs listed in the abridged South African Hypertension Guidelines of 2011 (Seedat \& Rayner, 2012). These classes were ACEinhibitors, beta blockers, calcium channel blockers, diuretics and angiotensin II antagonists. All drugs listed under each class were categorised according to their classification in the South African Medicines Formulary, 10th edition (Division of Clinical Pharmacology, 2012).

Data on South African private sector prices of originator and generic drugs was sourced from the South African Medicine Price Registry which is the official website that communicates drug prices as approved by the Pharmaceutical Economic Evaluation Unit of the Department of Health (South African Medicine Price Registry). The number of registered brands as at 10 June 2013 for each drug preparation was obtained from the registry. Drugs chosen under each medication were only included if there was a generic drug and originator price available. Combination preparations were excluded as they tend to alter the classification of the drug.

Originator pharmaceutical products were those initially registered by the innovator research-based pharmaceutical manufacturer on the basis of the documentation of their efficacy, safety and quality, whereas generic drugs were those usually intended to be interchangeable with the originator brand product, of the same strength and dosage form, registered after patent expiry or as licensed by the patent holder. Originator generic drugs were defined as generic drugs that were manufactured by the company that also manufactured the originator drug. Due to the differences in pack sizes 
between originator and generic drugs, the SEP, inclusive of the value-added tax per standard unit (i.e. price per tablet or capsule), was computed.

The price differential between originator and generic drugs was calculated as the difference between the price per standard unit of the originator drug and the median price per standard unit of available generic drugs expressed as a percentage of the price per standard unit of the originator drug. The relationship between the median proportional price (in percentage) and the number of brands was analysed by means of a correlation analysis. It was hypothesised that the price differential would be larger when the number of generic drugs on the market increased.

Reference prices were obtained from the Management Sciences for Health (MSH) International Drug Price Indicator Guide (2012 edition) (Frye, 2013). These constitute internationally recognised prices, based on current catalogues and price lists obtained from pharmaceutical suppliers, international development organisations, and government agencies. Price comparisons were made only for the originator drugs and the lowest price generic drugs where the median buyer international reference price (IRP) values were available. Price summaries were expressed as ratios relative to a standard set of reference prices. The ratio indicates how many times more or less the comparator drug is than the IRP. For international price comparisons, the exchange rate used was that of the first day of data collection from Google Finance ( $1 \mathrm{ZAR}=0.1017$ US $\$$ on 30 July 2013). All data was analysed using Microsoft Excel version 2010.

\section{Results}

The findings relate to prices of the different available strengths of 23 originator medicines and their generic equivalents. Table 1 reflects the private sector prices of originator and generic drugs sourced from the South African Medicine Price Registry on the 10th June 2013.

As indicated in Table 1, the largest therapeutic class are the angiotensin-converting enzyme (ACE) inhibitors with six drug products, followed by beta blockers and angiotensin-receptor blockers (ARB) with five and four drug products respectively. The total number of brands for the different strengths of the 23 drug products is 346, of which 120 are ACE inhibitors, 74 beta blockers, 61 calcium channel blockers (CCBs), 50 ARBs, 30 diuretics and 11 CCBs (non-dihydropyridine). Older generics drugs (e.g. captopril) that have been off-patent several years back have more registered brands than newer off-patent drugs (e.g. telmisartan).

Table 1 reveals considerable variability in the number of drugs under each class as well as in the number of registered brands for each drug preparation. A cursory look at Table 1 also reveals that drug products with higher number of registered brands generally have higher median cost differentials between originator and generic versions compared to drug preparations with lower number of registered brands. Competition theory (effect of the number of generic equivalents) was tested statistically between the price of the originator drug and generic drugs, between generic drugs, and finally between the originator drug and the generic version of the drug manufactured by the originator firm. It was hypothesised that increased generic entry would result in price competition and a reduction in drug prices suggesting that the calculated price differential would be larger as the number of generic drugs on the market increased. Of the 346 branded drugs, the median cost differential was $50.4 \%$ (interquartile range $40.1 \%-56.98 \%$ ). Of all the generic drugs identified, $75 \%$ were more than $40 \%$ cheaper than the branded version.

Of the 23 cardiovascular drugs, four originator companies manufactured a generic version of the drug. Table 2 shows the cost differentials between originator and generic versions manufactured by the originator for each of the available strengths of the drug. The median cost differential between originator and generic versions manufactured by the originator was $32.7 \%$ (interquartile range $22.96-41.89 \%$ ). A weak correlation between the number of generics and the size of the cost differential was apparent (correlation coefficient -0.48 ).

Fig. 1 represents the median prices of the different available strengths for the four originator generic drugs in comparison to the originator drug, and the corresponding highest priced generic. With the exception of telmisartan for which there were no other generic drugs available, the price of the originator generic was still higher than the most expensive generic version manufactured by any other company. There was no price difference between the originator and the originator generic version for bisoprolol.

Table 3 presents the results of different classes of cardiovascular drugs and the correlation coefficient for median cost differentials between originator and generic drugs as well as the correlation coefficient for median cost differentials between generic drugs for each drug class. The negative value indicates an inverse relationship which shows that even within the different classes of cardiovascular drugs, an increase in the number of available brands does not result in a reduction in drug prices. With the exception of diuretics, the remaining drug classes display a weak correlation between the number of generics and the size of the cost differential.

Reference pricing allows for comparisons to be drawn between South Africa and international countries. Table 4 indicates that in South Africa there are large variations between originator and generic prices and, secondly, that the lowest prices for medications are not always being attained.

Of the 20 drugs that were compared, none of originator drugs or lowest priced generics resulted in a ratio of one or less. According to the MSH, it is generally accepted that procurement prices for the lowest priced generics should be fairly close to the MSH international supplier/buyer prices (that is, ratios up to 1.00). These results indicate that the SEP policy has not resulted in very competitive prices for drugs. The originator drug prices had a median MPR of 20.99 (interquartile range 7.31-53.46), with atenolol having the highest median MPR and the lowest priced generics had a median MPR of 4.28 (interquartile range $2.10-8.47$ ), with enalapril having the highest MPR.

\section{Discussion}

Generic drug entry stimulates competition among the various brands of the off-patent product available in the market and 
Table 1 - Private sector prices of originator and generic drugs sourced from the South African Medicine Price Registry (10 June 2013).

Drug strength

Median cost differentials Minil and generic drugs

\begin{tabular}{|c|c|c|c|c|c|}
\hline Captopril $12.5 \mathrm{mg}$ & ACE inhibitor & 73.72 & 0.58 & 2.20 & 2 \\
\hline Captopril 25 mg & ACE inhibitor & 86.01 & 0.24 & 2.82 & 9 \\
\hline Enalapril $10 \mathrm{mg}$ & ACE inhibitor & 14.63 & 1.02 & 1.55 & 8 \\
\hline Enalapril 20 mg & ACE inhibitor & 19.44 & 1.35 & 2.84 & 7 \\
\hline Enalapril $5 \mathrm{mg}$ & ACE inhibitor & 17.06 & 0.59 & 1.12 & 7 \\
\hline Perindopril $10 \mathrm{mg}$ & ACE inhibitor & 39.30 & 4.19 & 6.90 & 2 \\
\hline Perindopril $2 \mathrm{mg}$ & ACE inhibitor & 53.69 & 2.82 & 6.09 & 2 \\
\hline Perindopril $4 \mathrm{mg}$ & ACE inhibitor & 42.79 & 1.32 & 4.56 & 15 \\
\hline Quinapril $10 \mathrm{mg}$ & ACE inhibitor & 56.14 & 1.34 & 4.15 & 3 \\
\hline Quinapril $20 \mathrm{mg}$ & ACE inhibitor & 60.30 & 2.03 & 5.85 & 4 \\
\hline Quinapril $40 \mathrm{mg}$ & ACE inhibitor & 41.91 & 3.65 & 6.28 & 2 \\
\hline Quinapril 5 mg & ACE inhibitor & 52.83 & 1.86 & 3.94 & 2 \\
\hline Ramipril $1.25 \mathrm{mg}$ & ACE inhibitor & 51.07 & 1.96 & 4.78 & 5 \\
\hline Ramipril $10 \mathrm{mg}$ & ACE inhibitor & 50.04 & 1.44 & 10.11 & 6 \\
\hline Ramipril $2.5 \mathrm{mg}$ & ACE inhibitor & 53.57 & 2.73 & 6.36 & 7 \\
\hline Ramipril $5 \mathrm{mg}$ & ACE inhibitor & 52.45 & 4.13 & 9.39 & 7 \\
\hline Lisinopril $10 \mathrm{mg}$ & ACE inhibitor & 38.88 & 0.68 & 2.80 & 10 \\
\hline Lisinopril $20 \mathrm{mg}$ & ACE inhibitor & 50.52 & 0.68 & 4.75 & 13 \\
\hline Lisinopril $5 \mathrm{mg}$ & ACE inhibitor & 37.78 & 0.683 & 1.96 & 9 \\
\hline Nifedipine $20 \mathrm{mg}$ & ССВ & 90.89 & 0.63 & 9.20 & 6 \\
\hline Nifedipine $30 \mathrm{mg}$ & ССВ & 44.87 & 4.34 & 8.38 & 6 \\
\hline Nifedipine $60 \mathrm{mg}$ & ССВ & 41.33 & 6.41 & 11.60 & 5 \\
\hline Amlodipine $10 \mathrm{mg}$ & ССВ & 49.25 & 2.09 & 7.09 & 20 \\
\hline Amlodipine $5 \mathrm{mg}$ & ССВ & 56.80 & 1.18 & 5.05 & 22 \\
\hline Felodipine $5 \mathrm{mg}$ & ССВ & 57.49 & 3.65 & 8.58 & 2 \\
\hline Propranolol $10 \mathrm{mg}$ & $\mathrm{BB}$ & 92.86 & 0.08 & 1.59 & 6 \\
\hline Propranolol $40 \mathrm{mg}$ & BB & 95.18 & 0.14 & 3.99 & 7 \\
\hline Atenolol $100 \mathrm{mg}$ & BB & 88.28 & 0.79 & 10.01 & 8 \\
\hline Atenolol $25 \mathrm{mg}$ & $\mathrm{BB}$ & 86.98 & 0.48 & 3.70 & 2 \\
\hline Atenolol $50 \mathrm{mg}$ & $\mathrm{BB}$ & 88.66 & 0.52 & 6.16 & 9 \\
\hline Acebutolol $400 \mathrm{mg}$ & BB & 26.50 & 6.86 & 9.33 & 2 \\
\hline Bisoprolol $10 \mathrm{mg}$ & $\mathrm{BB}$ & 45.21 & 2.53 & 4.91 & 8 \\
\hline Bisoprolol $5 \mathrm{mg}$ & BB & 48.39 & 1.5 & 3.10 & 8 \\
\hline Carvedilol $1.25 \mathrm{mg}$ & BB & 53.02 & 2.07 & 4.66 & 8 \\
\hline Carvedilol $25 \mathrm{mg}$ & BB & 40.41 & 2.61 & 4.661 & 8 \\
\hline Carvedilol $6.25 \mathrm{mg}$ & BB & 54.44 & 1.72 & 4.47 & 8 \\
\hline Indapamide $1.5 \mathrm{mg}$ & Diuretics & 65.13 & 1.06 & 3.03 & 2 \\
\hline Indapamide $2.5 \mathrm{mg}$ & Diuretics & 84.42 & 0.44 & 3.83 & 12 \\
\hline Furosemide $40 \mathrm{mg}$ & Diuretics (loop) & 95.76 & 0.12 & 4.29 & 11 \\
\hline Spironolactone $100 \mathrm{mg}$ & $\begin{array}{l}\text { Diuretics } \\
\text { (anti-aldosterone) }\end{array}$ & 0.00 & 6.91 & 6.91 & 2 \\
\hline Spironolactone $25 \mathrm{mg}$ & $\begin{array}{l}\text { Diuretics } \\
\text { (anti-aldosterone) }\end{array}$ & 2.18 & 1.07 & 1.12 & 3 \\
\hline Losartan $100 \mathrm{mg}$ & ARB & 8.22 & 2.53 & 3.02 & 11 \\
\hline Losartan $50 \mathrm{mg}$ & ARB & 19.09 & 1.35 & 3.02 & 15 \\
\hline Irbesartan $150 \mathrm{mg}$ & ARB & 51.84 & 1.49 & 8.16 & 4 \\
\hline Irbesartan $300 \mathrm{mg}$ & $\mathrm{ARB}$ & 50.81 & 1.49 & 7.99 & 4 \\
\hline Valsartan $160 \mathrm{mg}$ & ARB & 50.20 & 1.25 & 7.49 & 6 \\
\hline Valsartan $80 \mathrm{mg}$ & ARB & 50.20 & 1.25 & 7.49 & 6 \\
\hline Telmisartan $40 \mathrm{mg}$ & ARB & 41.89 & 4.84 & 8.33 & 2 \\
\hline Telmisartan $80 \mathrm{mg}$ & $\mathrm{ARB}$ & 41.89 & 4.84 & 8.33 & 2 \\
\hline Verapamil 240 mg & $\begin{array}{l}\text { CCB (non- } \\
\text { dihydropyridine) }\end{array}$ & 24.36 & 3.80 & 5.89 & 5 \\
\hline Verapamil 40 mg & $\begin{array}{l}\text { CCB (non- } \\
\text { dihydropyridine) }\end{array}$ & 51.35 & 0.38 & 0.90 & 4 \\
\hline Diltiazem 240 mg & $\begin{array}{l}\text { CCB (non- } \\
\text { dihydropyridine) }\end{array}$ & 21.24 & 7.25 & 9.21 & 2 \\
\hline
\end{tabular}

* ACE inhibitor-angiotensin-converting enzyme inhibitor; BB - beta blocker; ARB - angiotensin receptor blocker; CCB - calcium channel blocker. 
Table 2 - Cost differentials associated with originator and originator generics.

\begin{tabular}{lcc} 
Drug name & $\begin{array}{c}\text { Number of } \\
\text { registered } \\
\text { brands identified }\end{array}$ & $\begin{array}{c}\text { Cost differential } \\
\text { between originator } \\
\text { and originator } \\
\text { generic drugs (\%) }\end{array}$ \\
\hline Bisoprolol 10 mg & 8 & 0 \\
Bisoprolol 5 mg & 8 & 0 \\
Telmisartan $40 \mathrm{mg}$ & 2 & 41.89 \\
Telmisartan $80 \mathrm{mg}$ & 2 & 41.89 \\
Irbesartan $150 \mathrm{mg}$ & 4 & 32.81 \\
Irbesartan 300 mg & 4 & 31.37 \\
Verapamil 240 mg & 5 & 12.19 \\
\hline
\end{tabular}

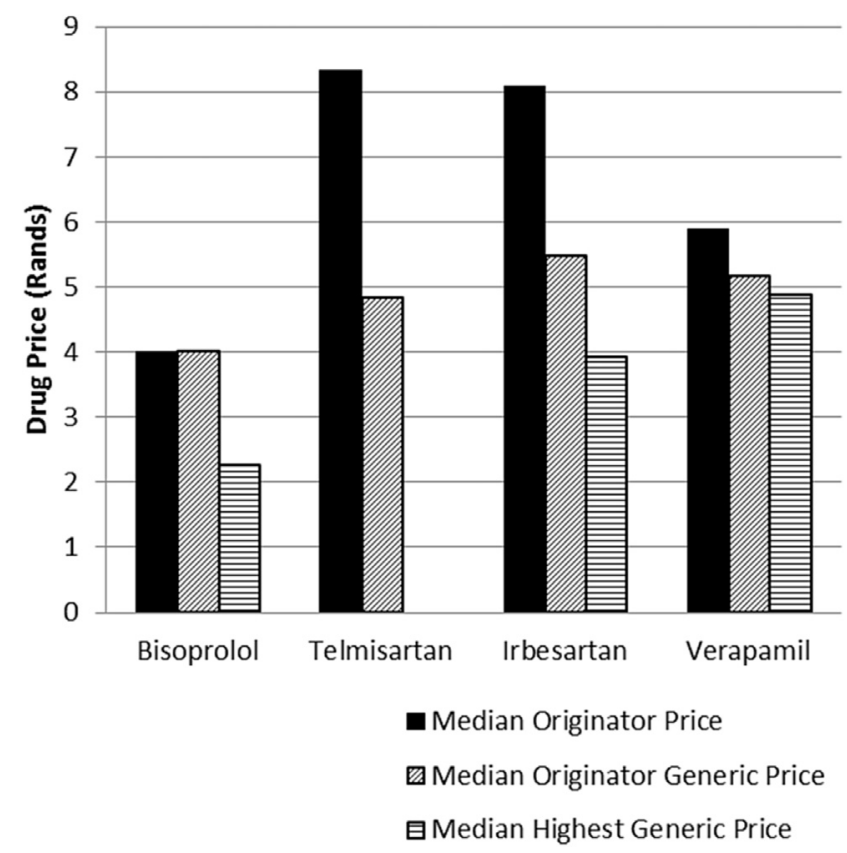

Fig. 1 - Comparison of prices for bisoprolol, telmisartan, Irbesartan and Verapamil.

assists in reducing the overall price of the drug product (Cook, 1998). However, this phenomenon is can only take place if there is a sufficient number of generic products in the market (King \& Kanavos, 2002). Several international studies have sought to characterise the relationship between the number of brands of a product and the effect on drug pricing. An American study by Wiggins and Maness (2004) explored price variation in anti-infective drugs and yielded different results from previous studies conducted on several random drugs. The study indicated that pricing variation may be sensitive to the class of generic drugs. The analysis further showed that increases in the number of competitors significantly reduced prices. These findings are consistent for unregulated markets without price caps and are consistent with findings of the Bresnahan and Reiss study (Bresnahan \& Reiss, 1991).

Fatokun et al. (2011) conducted a study in Malaysia examining the relationship between the number of multisource drugs and their proportional prices. The results confirmed the price-lowering effect of generic competition as shown by the decrease in the mean proportional price as the number of brands of the product increases. This generic price-lowering effect was, however, not observable across all therapeutic classes.

Adriean, De Witte, and Simoens (2008) in researching the determinants of pricing strategies of originator and generic drugs following patent expiry in Belgium revealed that pricing strategies of originator and generic drugs are dependent on the therapeutic class, with the price differential between originator and generic drugs being higher for the cardiovascular class of drugs. Pricing strategies were further influenced by regulatory aspects such as successive reductions in reference prices and prescription status of drugs, market incentives in the form of price competition between generic drugs, competition between originator and generic drugs, and the market power of the manufacturer of the originator drug.

The results from our analysis did not indicate that there was a price-lowering effect with increased generic competition. When testing the competition hypothesis between originator drugs and generic drugs and between generic drugs themselves, the correlation was found to be very weak in both instances, with the exception of diuretics.

A wide variation between the price of the least expensive brands and the most expensive brands was observed. One explanation for this observation is that the originator companies do not engage in price competition with generic brands (Kanavos \& Vandoros, 2011). This is supported by the second finding. When the price of the generic drug manufactured by an originator company was compared to the median generic drug price, these drugs were found to be consistently higher, suggesting that originator companies may set the price ceiling for other generic products.

The only published pricing study for South Africa was conducted in Gauteng. This study used the WHO and Health Action International methodology and revealed that the majority of drug prices did not compare well with the international reference price (Xiphu \& Mpanza, 2004). This was before SEP was implemented. Similarly, our findings revealed high prices for drugs when compared with buyer international prices ranging from 2.69 times greater to a staggering 115.97 times greater for originator drugs. These results indicate that current pharmaceutical policies are not optimal in South Africa even though the use of generic drugs is increasing for all classes of drugs in this study; an increase in generic usage has thus not led to lower drug prices.

Medicine availability and pricing studies using the same methodology in developing and middle-income countries have been conducted (Cameron, Ewen, Ross-Degnan, Ball, \& Laing, 2009). Traditionally these studies have focused on a core list of drugs targeting acute and chronic conditions, as opposed to a defined therapeutic class of drugs. A study conducted by van Mourik et al. (2010), however, opted to compare the availability, price and affordability of cardiovascular medicines (atenolol, captopril, hydrochlorothiazide, losartan and nifedipine) across 36 countries using WHO/HAI data. The results of the study showed great variability with regard to procurement prices, where some countries were very competitive and others consistently paid high prices. In addition, patient prices were generally substantially higher than international references prices in some of the countries 
Table 3 - Correlation coefficient results for each drug class.

\begin{tabular}{lcc} 
Drug class & $\begin{array}{c}\text { Correlation coefficient } \\
\text { (median cost differentials } \\
\text { between originator } \\
\text { and generic drugs) }\end{array}$ & $\begin{array}{c}\text { Correlation } \\
\text { coefficient } \\
\text { (between } \\
\text { generic drugs) }\end{array}$ \\
\hline ACE inhibitor & -0.19 & 0.08 \\
Calcium channel & -0.12 & 0.04 \\
$\quad$ blocker & 0.07 & 0.51 \\
Beta blocker & 0.78 & 0.92 \\
Diuretics & -0.77 & -0.39 \\
Angiotensin- & & \\
$\quad$ receptor & & \\
$\quad$ blocker & 0.28 & \\
Calcium-channel & & \\
$\quad$ blockers: non- \\
dihydropyridine
\end{tabular}

that were surveyed. An interesting finding from the study was that chronic treatment with anti-hypertensive medicines became unaffordable when monotherapy was insufficient. Ideally further research should be undertaken to identify the success behind lower prices obtained in these surveyed countries, and to determine whether these polices could not be implemented in South Africa to obtain similar results.

\subsection{Limitations of the study}

The main limitation noted was the lack of information on international prices for all drugs used in the study in order to make informed conclusive judgements on price comparisons. Moreover, the study reflects results from one therapeutic class only.

\subsection{Recommendations}

It is recommended that a study be undertaken which examines the market trends and the effects of SEP on generic drug competition across all therapeutic classes, with particular emphasis on diseases that rank as high priority in South Africa. Results from such a study would aid policy-makers in selectively tailoring policies to address the current high costs of healthcare.

\section{Conclusion}

While the pro-generic legislation may seek to increase accessibility to medicines and improved healthcare, the implementation of SEP may result in unintended long-term effects by interfering with the normal market processes. Alternative price regulations may promote active competition among generic drug producers thus avoiding the observed behaviour of drug prices clumping together. Interestingly, the study revealed that the majority of generic drugs in the dataset were more than $40 \%$ cheaper than the branded versions, which was the proposed government price at which generic drugs will be pegged at in South Africa, which provides some assurance of the cost-reducing impact of generic drug substitution.

The marked differences between the high South African medicine prices and international prices warrant the implementation of future policy evaluations as well as possible pricing interventions such as benchmarking and reference pricing in an effort to lower drug prices. More work is required to identify the determinants of the price differentials between originator and generic drugs in South Africa, particularly in light of the newly proposed healthcare restructuring.

Table 4 - Comparison of median price ratios (MPR) with IRP values.

\begin{tabular}{|c|c|c|c|}
\hline & $\begin{array}{l}\text { IRP unit price (US\$) } \\
\text { (buyer price) }\end{array}$ & $\begin{array}{c}\mathrm{MPR}^{\mathrm{a}} \text { for originator drug } \\
\text { unit price (US\$) }\end{array}$ & $\begin{array}{l}\mathrm{MPR}^{\mathrm{a}} \text { for lowest price } \\
\text { generic unit price (US\$) }\end{array}$ \\
\hline Captopril 25 mg & 0.01 & 25.41 & 2.16 \\
\hline Enalapril $10 \mathrm{mg}$ & 0.01 & 28.71 & 18.78 \\
\hline Enalapril $20 \mathrm{mg}$ & 0.01 & 38.03 & 18.02 \\
\hline Perindopril $4 \mathrm{mg}$ & 0.04 & 11.98 & 3.48 \\
\hline Nifedipine $20 \mathrm{mg} \mathrm{Sr}$ & 0.02 & 62.36 & 4.27 \\
\hline Amlodipine $10 \mathrm{mg}$ & 0.01 & 55.93 & 16.48 \\
\hline Amlodipine $5 \mathrm{mg}$ & 0.01 & 47.59 & 11.11 \\
\hline Propranolol $10 \mathrm{mg}$ & 0.05 & 3.28 & 0.16 \\
\hline Propranolol $40 \mathrm{mg}$ & 0.01 & 52.64 & 1.79 \\
\hline Atenolol $100 \mathrm{mg}$ & 0.01 & 99.83 & 7.88 \\
\hline Atenolol $50 \mathrm{mg}$ & 0.01 & 115.97 & 9.79 \\
\hline Carvedilol $12.5 \mathrm{mg}$ & 0.05 & 9.64 & 4.29 \\
\hline Carvedilol $25 \mathrm{mg}$ & 0.05 & 8.79 & 4.92 \\
\hline Carvedilol $6.25 \mathrm{mg}$ & 0.09 & 4.94 & 1.90 \\
\hline Furosemide $40 \mathrm{mg}$ & 0.01 & 65.10 & 1.82 \\
\hline Spironolactone $100 \mathrm{mg}$ & 0.09 & 8.03 & 8.03 \\
\hline Spironolactone $25 \mathrm{mg}$ & 0.03 & 3.36 & 3.22 \\
\hline Losartan $50 \mathrm{mg}$ & 0.02 & 16.57 & 7.44 \\
\hline Verapamil 240 mg Sr & 0.12 & 5.14 & 3.32 \\
\hline Verapamil $40 \mathrm{mg}$ & 0.034 & 2.69 & 1.13 \\
\hline
\end{tabular}




\section{Author contribution}

F.S. was the project leader and responsible for conceptualising and designing the project, as well as obtaining access to the databases.

V.B. was responsible for the data collection, analysis, and writing of the manuscript, while F.S. provided critical revisions to the final manuscript before submission. Both authors agreed on the version of the manuscript that was submitted and the final revised and edited version.

\section{Research significance}

Generic competition may be affected by other pricing policies and requires careful monitoring within countries.

Pricing studies for medicines within therapeutic classes are required to determine if there is competition within therapeutic classes where generic medicines are available.

\section{Acknowledgements}

The statements, findings, conclusions, views, and opinions contained in this article are based in part on data obtained under licence from the following IMS Health (Proprietary) Limited (South Africa) information service(s): IGMS (International Market Segmentation) Audit and Total Private Market for the period 2010 - 06/2013, IMS Health (Proprietary) Limited (South Africa). The statements, findings, conclusions, views, and opinions contained herein are not necessarily those of IMS Health Incorporated or any of its affiliated or subsidiary entities.

\section{R E F E R E N C E S}

Adriean, M., De Witte, K., \& Simoens, S. (2008). Pricing strategies of originator and generic medicines following patent expiry in Belgium. Journal of Generic Medicines: The Business Journal for the Generic Medicines Sector, 5, 175-187.

Bangalee, V. (2015). South African patient's acceptance of generic drugs. African Health Sciences, 15(1), 281-282.

Bresnahan, T. F., \& Reiss, P. C. (1991). Entry and competition in concentrated markets. Journal of Political Economy, 99, 977-1009.

Cameron, A., Ewen, M., Ross-Degnan, D., Ball, D., \& Laing, R. (2009). Medicine prices, availability, and affordability in 36 developing and middle-income countries: a secondary analysis. The Lancet, 373(9659), 240-249.
Cook, A. (1998). How increased competition from generic drugs has affected prices and returns in the pharmaceutical industry. Washington, D.C:: Congressional Budget Office.

Deroukakis, M. (2007). Mandatory substitution successful: original article. South African Medical Journal, 97(1), 63-64.

Division Of Clinical Pharmacology. (2012). South African medicines formulary. Faculty of Health Sciences \& University of Cape Town. Cape Town: Health and Medical Publishing Group.

Fatokun, O., Ibrahim, M. I. M., \& Hassali, M. A. (2011). Generic competition and drug prices in the Malaysian off-patent pharmaceutical market. Journal of Applied Pharmaceutical Science, 1, 33-37.

Frye, J. E. (2013). International drug price indicator guide - 2012 edition. Available from: http://erc.msh.org/dmpguide/pdf/ DrugPriceGuide_2012_en.pdf.

Hawkins, L. (2011). Review series on pharmaceutical pricing policies and interventions: Working paper 4: Competition policy. Available from: http://www.haiweb.org/medicineprices/24072012/ CompetitionFinalMay2011.pdf.

Kanavos, P., \& Vandoros, S. (2011). Determinants of branded prescription medicine prices in OECD countries. Health Economics Policy and Law, 6, 313-335.

King, D. R., \& Kanavos, P. (2002). Encouraging the use of generic medicines: implications for transition economies. Croatian Medical Journal, 43, 462-469.

Lopez, A. D., Mathers, C. D., Ezzati, M., Jamison, D. T., \& Murray, C. J. (2006). Global and regional burden of disease and risk factors, 2001: systematic analysis of population health data. The Lancet, 367(9524), 1747-1757.

Moorad, Z. (2012). Generic pharmaceutical market set for bumper year. Available from: http://bhfglobal.com/generic-pharmaceuticalmarket-set-bumper-year-2022012.

van Mourik, M. S. M., Cameron, A., Ewen, M., \& Laing, R. O. (2010). Availability, price and affordability of cardiovascular medicines: a comparison across 36 countries using WHO/HAI data. BMC Cardiovascular Disorders, 10(25). Available from: http://www.biomedcentral.com/1471-2261/10/25.

Nicolosi, E., \& Gray, A. (2009). Potential cost savings from generic medicines - protecting the prescribed minimum benefits. South African Family Practice, 51, 59-63.

Republic of South Africa. Medicines and Related Substances Amendment Act (Act 90 of 1997). Available from: http://www. gov.za/sites/www.gov.za/files/a90-97.pdf.

Seedat, Y. K., \& Rayner, B. L. (2012). South African hypertension guideline 2011. The South African Medical Journal, 102, 57-88.

South African Medicine Price Registry. Database of medicine prices 10 June 2013. Available from: http://www.mpr.gov.za/.

Steyn, K. (2007). Heart disease in South Africa. Available from: http://www.mrc.ac.za/chronic/heartandstroke.pdf.

Wiggins, S. N., \& Maness, R. (2004). Price competition in pharmaceuticals: the case of anti-infectives. Economic Inquiry, 42, 247-263.

Xiphu, L., \& Mpanza, N. (2004). Medicine prices survey in the Gauteng province in South Africa. Available from: http://www. haiweb.org/medicineprices/surveys/200411ZAG/survey_ report.pdf. 